Article

\title{
Experimental Study on Unconfined Compression Strength of Polypropylene Fiber Reinforced Composite Cemented Clay
}

\author{
Qiangqiang Cheng ${ }^{1,2}$, Jixiong Zhang ${ }^{2, *}$, Nan Zhou ${ }^{2}$, Yu Guo ${ }^{1}$ and Shining Pan ${ }^{1}$ \\ 1 School of Architectural Construction, Institute of Applied Technology of Construction Industrialization \\ and Information, Jiangsu Vocational Institute of Architectural Technology, Xuzhou 221116, China; \\ qiangcheng@cumt.edu.cn (Q.C.); hnnygy@126.com (Y.G.); panshining@163.com (S.P.) \\ 2 State Key Laboratory of Coal Resources and Safe Mining, China University of Mining \& Technology, \\ Xuzhou 221116, China; zhounanyou@126.com \\ * Correspondence: zjxiong@163.com
}

Received: 3 March 2020; Accepted: 23 March 2020; Published: 26 March 2020

\begin{abstract}
The effects of three main factors, including polypropylene fiber content, composite cement content and curing time on the unconfined compressive strength of fiber-reinforced cemented clay were studied through a series of unconfined compressive strength tests. The experimental results show that the incorporation of fibers can increase the compressive strength and residual strength of cement-reinforced clay as well as the corresponding axial strain when the stress peak is reached compared with cement-reinforced clay. The compressive strength of fiber-reinforced cement clay decreases first, then increases with small-composite cement at curing time $14 \mathrm{~d}$ and $28 \mathrm{~d}$. However, fiber-reinforced cement clay's strength increases with the increase of fiber content for heavy-composite cement. The compressive strength of fiber-composite cement-reinforced marine clay increases with the increase of curing time and composite cement content. The growth rate increases with the increase of curing time. The failure mode of composite cement-reinforced clay is brittle failure, while the failure mode of fiber-reinforced cemented clay is plastic failure.
\end{abstract}

Keywords: fiber-reinforced cemented clay; unconfined compression strength; fiber content; composite cement content; curing time

\section{Introduction}

Marine clays have the characteristics of large pore ratios, high water content, low shear strength, soft sensitive and high compressibility [1,2]. Soft clays are widely present in offshore areas and cannot be used directly in geotechnical engineering activities, such as subgrade engineering, embankments, deep excavation and underground construction. Considering the economy and effectiveness, using cement to reinforce soft clay is of great popularity [3-8], compared with other chemical stabilization methods. Though cement-stabilized clay has the advantages of rapid formation, good plasticity and high compressive strength, it also has the disadvantages of low tensile strength and flexural strength. A number of studies that used fly ash, a by-product of coal or solid waste, to partially replace cement for improving the mechanical strength of cement-stabilized clay have been carried out [9-11]. Zentar et al. [12] conducted experimental investigations into the tensile strength and unconfined compressive strength of solidified marine sediments using siliceous-aluminous fly ash and cement. Through laboratory-unconfined compression tests, split tensile tests, bender element tests and isotropic compression tests conducted by Xiao et al. [13], a semiempirical relationship between compressive strength and curing time for fly ash-blended cement-stabilized marine clay has been obtained. A series of laboratory experiments, including isotropic compression, triaxial drained shearing, unconfined 
compression and bender element testing were carried out by Cheng et al. [14], in which the primary yielding and yield locus of fly ash cement-stabilized marine clay were investigated.

Polypropylene fiber is characterized by light weight, high tensile strength and low energy consumption. The strength and deformation resistance of cement-stabilized soils can be improved by incorporating appropriate fibers [15-17]. Many studies have been carried out on the properties of polypropylene fiber-reinforced cement-stabilized soils. Correia et al. [18] conducted experiments and concluded the compressive and tensile strength characteristics of polypropylene fiber-reinforced blast furnace slag solidified Portuguese soft soils. Through laboratory-split tensile tests conducted by Xiao et al. [19]—as well as stochastic finite element theory—a prediction model for tensile strength of polypropylene / polyvinyl alcohol fiber-modified cement-stabilized clay was established considering the fiber length and content. Ding et al. [20] studied the effect of freeze-thaw cycles on the mechanical properties of polypropylene fiber-reinforced cement-stabilized clay; the relationships among sample size, residual stress ratio, tangent modulus, cement content, fiber content and number of freeze-thaw cycles were established. The tensile strength of cement-stabilized marine clay reinforced by short waste fibers was investigated by Li et al. [21]. Through experimental and numerical methods, a numerical simulation of a single fiber pullout from a matrix was established by using a cohesive contact model.

Compared with the prevalence of studies on unconfined compression strength, there have been fewer studies on the compressive characteristics of fiber-reinforced fly ash-cemented clay. This paper presents a study on the effect of polypropylene fiber content, composite cement content and curing time on the unconfined compression strength of polypropylene fiber-composite cement-reinforced marine clay by using experimental tests, in order to provide reference for the future application of polypropylene fiber in soft clay foundations.

\section{Materials and Experimental Methodology}

\subsection{Materials}

The studied materials mainly included marine clay, fly ash cement and polypropylene fibers. The clay used in the test was Singapore marine clay excavated from a subway station with characteristics of grayish brown, saturated, obvious rheological properties, high compressibility and low bearing capacity. The main physical characteristics of the marine clay are presented in Table 1 . The marine clay was put into a PVC plastic shading bucket and transported to the laboratory for backup. The water content of marine clay was approximately $88 \%$. The liquid limit and plastic limit of marine clay were, respectively, $73 \%$ and $32 \%$.

Table 1. Physical characteristics of marine clay.

\begin{tabular}{ccccc}
\hline $\begin{array}{c}\text { Water Content } \\
(\mathbf{\%})\end{array}$ & $\begin{array}{c}\text { Specific Gravity, Gs } \\
\left(\mathbf{M g} / \mathbf{m}^{\mathbf{3}}\right)\end{array}$ & $\begin{array}{c}\text { Liquid Limit } \\
\mathbf{( \% )}\end{array}$ & $\begin{array}{c}\text { Plastic Limit } \\
\mathbf{( \% )}\end{array}$ & $\begin{array}{c}\text { Plasticity Index } \\
(\mathbf{\%})\end{array}$ \\
\hline 88 & 2.7 & 73 & 32 & 41 \\
\hline
\end{tabular}

The test cement is CEM II / B-V commercial composite cement and its physical and mechanical indexes are shown in Table 2. The mass ratio of fly ash to ordinary cement in CEM II / B-V commercial composite cement is 0.345:0.655; its main chemical components are $\mathrm{SiO}_{2}, \mathrm{Al}_{2} \mathrm{O}_{3}, \mathrm{Fe}_{2} \mathrm{O}_{3}, \mathrm{MgO}$ and $\mathrm{CaO}$.

Table 2. Indexes of mechanical properties of fly ash cement.

\begin{tabular}{cccccccc}
\hline $\begin{array}{c}\text { Initial Setting } \\
\text { Time (h) }\end{array}$ & $\begin{array}{c}\text { Final Setting } \\
\text { Time (h) }\end{array}$ & Stability & $\begin{array}{c}\text { Loss on } \\
\text { Ignition } \\
(\%)\end{array}$ & $\begin{array}{c}\text { Compressive Strength } \\
\mathbf{( M P a )}\end{array}$ & \multicolumn{2}{c}{$\begin{array}{c}\text { Flexural Strength } \\
\mathbf{( M P a )}\end{array}$} \\
\hline $2: 30$ & $4: 00$ & Qualified & 1.3 & 24 & $\mathbf{2 8 ~ d}$ & $\mathbf{3 ~ d ~}$ & $\mathbf{2 8 ~ d ~}$ \\
\hline
\end{tabular}


The polypropylene fibers used in the test were chopped 6-mm commercial fibers. The main physical and mechanical characteristics of polypropylene fibers are shown in Table 3.

Table 3. Physical and mechanical characteristics of polypropylene fibers.

\begin{tabular}{cccccc}
\hline Type & $\begin{array}{c}\text { Density } \\
\left(\mathrm{g} / \mathrm{cm}^{3}\right)\end{array}$ & $\begin{array}{c}\text { Length } \\
(\mathbf{m m})\end{array}$ & $\begin{array}{c}\text { Tensile Strength } \\
(\mathbf{M P a})\end{array}$ & $\begin{array}{c}\text { Acid and Alkali } \\
\text { Resistance }\end{array}$ & Dispersion \\
\hline Monofilament & 0.91 & 6 & $>360$ & High performance & Good \\
\hline
\end{tabular}

\subsection{Experiment Scheme}

The definition of compound composite content, polypropylene fiber content and water content are shown in Equations (1)-(3), respectively. The fly ash cement content was adopted based on applications in practice, such as the improvement of an ending shaft to supporting a tunnel boring machine. The fiber content was determined as the common values used in foundation pit project and subgrade engineering.

$$
\begin{gathered}
C_{c}=M_{\mathcal{c}} / M_{s} \times 100 \% \\
C_{f}=M_{f} / M_{s} \times 100 \% \\
C_{w}=M_{w} /\left(M_{s}+M_{c}\right) \times 100 \%
\end{gathered}
$$

where $C_{c}$ is fly ash cement content, $C_{f}$ is polypropylene fiber content, $C_{w}$ is water content, $M_{c}$ is the quality of fly ash cement, $M_{S}$ is the quality of dry soil in the marine clay, $M_{f}$ is the quality of polypropylene fiber, $M_{w}$ is the quality of water.

An orthogonal design method was used to study the influence of factors such as fiber content, composite cement content and curing time on the unconfined compressive strength of polypropylene fiber-reinforced fly ash-cemented marine clay. The test scheme is shown in Table 4. Considering test

\begin{tabular}{|c|c|c|c|}
\hline $\begin{array}{l}\text { Polypropylene Fiber Content } \\
\qquad(\%)\end{array}$ & $\begin{array}{c}\text { Fly Ash Cement Content } \\
(\%)\end{array}$ & Curing Time (d) & Water Content $(\%)$ \\
\hline \multirow{3}{*}{0} & $20,50,100$ & 7 & \\
\hline & $20,50,100$ & 14 & \\
\hline & $20,50,100$ & 28 & \\
\hline \multirow{3}{*}{0.5} & $20,50,100$ & 7 & \\
\hline & $20,50,100$ & 14 & 100 \\
\hline & $20,50,100$ & 28 & \\
\hline \multirow{3}{*}{1} & $20,50,100$ & 7 & \\
\hline & $20,50,100$ & 14 & \\
\hline & $20,50,100$ & 28 & \\
\hline
\end{tabular}
error factors such as sample heterogeneity, 5 samples were conducted in each group.

Table 4. The test scheme of the unconfined compressive strength.

\subsection{Sample Preparation and Testing}

The obvious plant roots, shells and other debris were removed from the marine clay at the site. Moreover, the sand particles are sieved with a 1-mm sieve. Samples were prepared in accordance with a procedure described by Chin et al. [22]. The reshaping of marine clay and the preparation method of triaxial samples were consistent with references $[6,14,23]$. According to the content of polypropylene fiber, composite cement and water in the test scheme, the required quality of marine clay, composite cement, fiber and water were weighed with a high-precision electronic scale. First, appropriate amount of water was added to the marine clay and stirred well. Secondly, the weighed composite cement was added and stirred well. Finally, the weighted polypropylene fibers were added and stirred well. The stirred fiber-reinforced flay ash cemented clay was put into a sealed plastic bag for later use. 
The PVC plastic mold with an inner diameter of $50 \mathrm{~mm}$ and a height of $100 \mathrm{~mm}$ was fastened and cleaned. One end of the mold with a plastic film was sealed and then a release agent evenly inside the mold was applied. The mixture of fiber-composite cement-reinforced clay was stirred evenly into the mold for 5 times. We ensured the mixture previously squeezed in was shaken evenly before the next squeeze. After the top of the sample that has been shaken uniformly was scraped with a spatula, the two ends of the mold were completely wrapped with labeled water-permeable filter paper and placed horizontally in the conservational water tank for indoor conservation to ensure that the specimen was not affected by any external force during the conservational process.

The cylindrical samples were taken out from the conservational water tank and wiped off the surface water when the curing time reached $7 \mathrm{~d}, 14 \mathrm{~d}$ and $28 \mathrm{~d}$, respectively. The experiment of unconfined compressive strength was conducted using a triaxial test device with a load at a constant rate of $1 \mathrm{~mm} / \mathrm{min}$ after the samples were scraped well. The relevant data during the test were collected. An unconfined compression test was performed by following the procedures prescribed in ISO/TS 17892 (2004) [24].

\section{Results and Discussion}

\subsection{Stress-Strain Behavior}

Figures $1-3$ present the curves of axial strain $\varepsilon-\delta$ with $0 \%, 0.5 \%$ and $1 \%$ polypropylene fiber content of the fiber-reinforced fly ash-cemented marine clay, respectively, depending on different mix ratio and curing time. All stress-strain curves show the peak strength of fiber-reinforced fly ash-cemented marine clay was significantly higher than that without polypropylene fiber, except the condition of $20 \%$ compound fly ash cement content. Compared with fly ash cement-reinforced marine clay, the residual strength deformation stage of the stress-strain curve of fiber-reinforced composite-cemented clay was more significant and the retention time of residual strength was much longer after reached the peak strength. Taking the $50 \%$ fly ash cement content and $0.5 \%$ fiber content as an example, the residual strength of the fiber-reinforced fly ash-cemented marine clay increased by $133.3 \%, 145.6 \%$ and $224.5 \%$ when the curing age was $7 \mathrm{~d}, 14 \mathrm{~d}$ and $28 \mathrm{~d}$, respectively, which shows that adding certain quality polypropylene fiber can effectively improve the residual strength of fly ash cement-reinforced marine clay. Moreover, the trend for the changes of curves of axial strain $\varepsilon-\delta$-as well as strength and stiffness without fiber with fly ash cement content and curing time-is similar to the observation reported in a previous study $[6,9,14]$. The researchers analyzed the structure with respect to the unconfined compression strength of fly ash cement-reinforced clay.

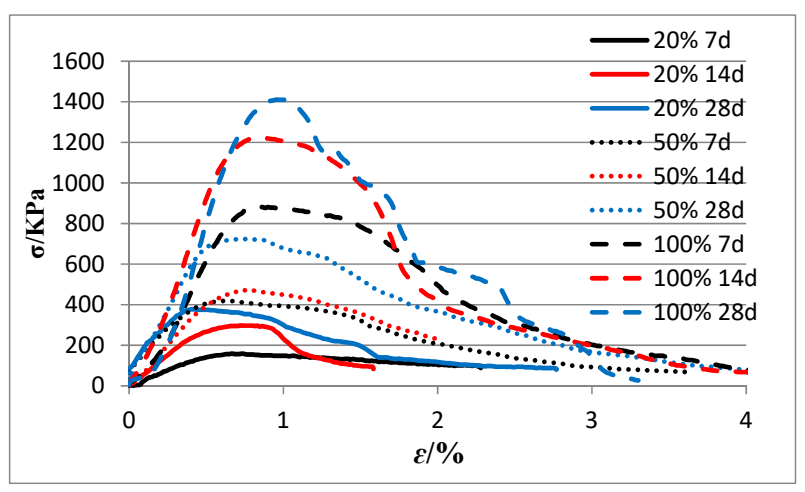

Figure 1. Curves of axial strain $\varepsilon-\delta$ without fiber depending on fly ash cement content and curing time. 


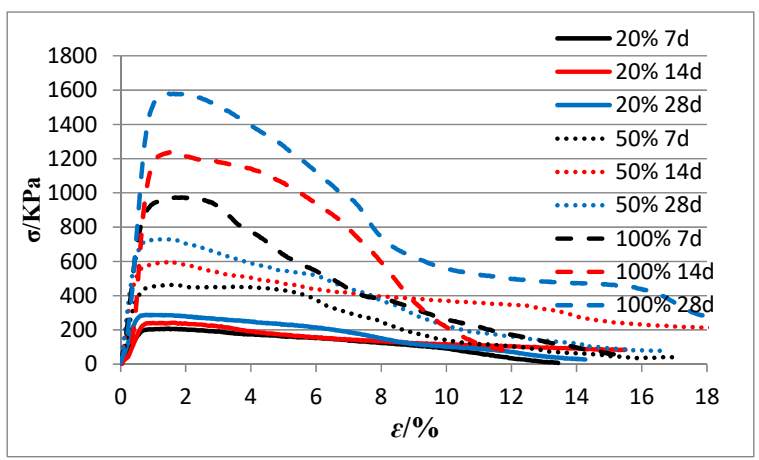

Figure 2. Curves of axial strain $\varepsilon-\delta$ with $0.5 \%$ fiber content depending on fly ash cement content and curing time.

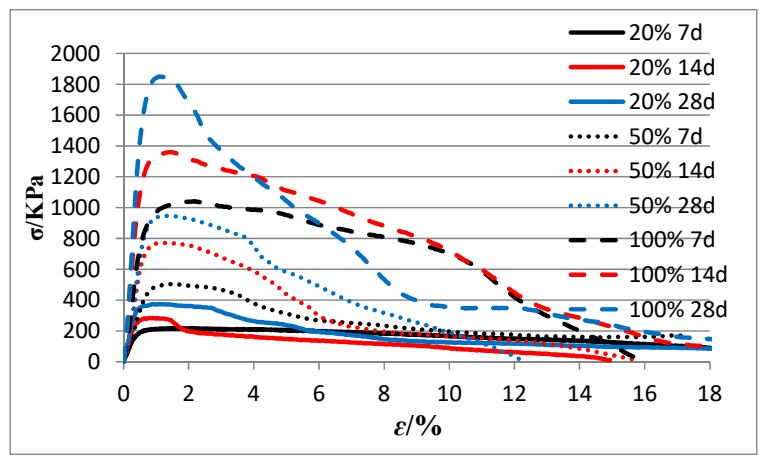

Figure 3. Curves of axial strain $\varepsilon-\delta$ with $1 \%$ fiber content depending on fly ash cement content and curing time.

The axial strain corresponding to the failure time of fiber-reinforced composite-cemented marine clay is shown in Table 5 . Taking the $50 \%$ fly ash cement content and $0.5 \%$ fiber content as an example, the axial strain at the failure time of the fiber-reinforced fly ash-cemented marine clay increased by $253.5 \%, 197.3 \%$ and $172.9 \%$ when the curing age is $7 \mathrm{~d}, 14 \mathrm{~d}$ and $28 \mathrm{~d}$, respectively. The axial strain at the time of failure of fiber-reinforced composite-cemented marine clay was much larger than that without polypropylene fiber under the same conditions, which indicates that the incorporation of polypropylene fiber can effectively improve the brittleness and toughness of the composite cement-reinforced marine clay. The main reason is that the composite cement-reinforced marine clay particles attached to the fiber surface can increase its cohesion and friction. The tensile stress between the fiber and the reinforced clay may continue for a long time though the specimen is already damaged, which means that the fiber can effectively reduce the deformation and improve the toughness and residual strength of the fly ash cement-reinforced marine clay.

Table 5. The axial strain at failure time of the fiber fly ash cement-reinforced marine clay.

\begin{tabular}{ccccc}
\hline \multirow{2}{*}{ Fly Ash Cement Content (\%) } & Curing Time (d) & \multicolumn{3}{c}{ Polypropylene Fiber Content (\%) } \\
& & $\mathbf{0}$ & $\mathbf{0 . 5}$ & $\mathbf{1}$ \\
\hline \multirow{2}{*}{20} & 7 & 0.668 & 1.474 & 1.604 \\
& 14 & 0.716 & 1.566 & 0.797 \\
\multirow{2}{*}{50} & 28 & 0.4 & 0.778 & 0.908 \\
& 7 & 0.63 & 1.597 & 1.427 \\
& 14 & 0.744 & 1.468 & 1.24 \\
\multirow{2}{*}{100} & 28 & 0.727 & 1.257 & 1.397 \\
& 7 & 0.865 & 1.855 & 2.17 \\
& 14 & 0.807 & 1.579 & 1.466 \\
& 28 & 0.952 & 1.483 & 1.083 \\
\hline
\end{tabular}




\subsection{Effect of Fiber Content on Unconfined Compressive Strength}

The relationship between the unconfined compressive strength and the fiber content of each group of samples depending on fly ash cement content and curing time is shown in Figure 4 . The figure indicates that the unconfined compressive strength of polypropylene fiber-reinforced composite-cemented marine clay increases at first and then decreases with the increase of fiber content when the composite cement content is $20 \%$, however, it keeps increase with the increase of fiber content when the composite cement content is $50 \%$ and $100 \%$. Taking the $50 \%$ fly ash cement content and $0.5 \%$ fiber content as an example, the unconfined compressive strength of the fiber-reinforced fly ash-cemented marine clay at curing time $7 \mathrm{~d}, 14 \mathrm{~d}$ and $28 \mathrm{~d}$ is 1.11 times, 1.27 times and 1.06 times, respectively, that of without polypropylene fiber. When the fiber content is $1 \%$ with the $50 \%$ fly ash cement content, the unconfined compressive strength of the fiber-reinforced fly ash-cemented marine clay is 1.20 times, 1.63 times and 1.31 times that of without polypropylene fiber, which indicates that with low fly ash cement content, the structure of composite cement-reinforced marine clay is not fully formed; the modification effect of polypropylene fiber on composite cement-reinforced clay is not obvious. However, when the content of fly ash cement is higher, adding appropriate amount of fiber can effectively increase its cohesion of the fly ash cement-reinforced marine clay, which can make the reinforcing effect of polypropylene fiber obvious. The mechanical performance of fiber-composite fly ash cement-reinforced clay with $0.5 \%$ fiber content is basically consistent with previous studies, however, it shows different characteristics with $1 \%$ fiber content $[16,17,22]$.

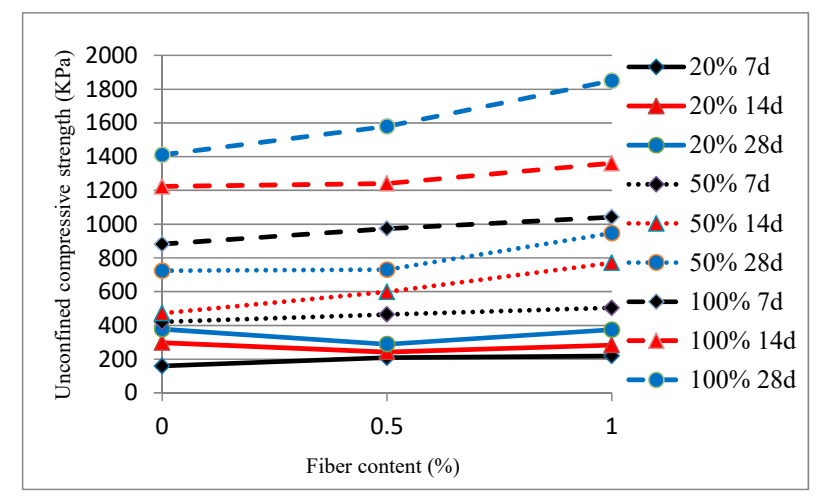

Figure 4. Relationship between unconfined compressive strength and fiber content depending on fly ash cement content and curing time.

\subsection{Effect of Fly Ash Cement Content on Unconfined Compressive Strength}

In order to study the effect of fly ash cement content on the unconfined compressive strength, the relationship depending on fiber content and curing time was studied, as shown in Figure 5. The figure indicates that the unconfined compressive strength of polypropylene fiber-reinforced fly ash-cemented marine clay increased with the increase of fly ash cement content. The increase trend of $14 \mathrm{~d}$ to $28 \mathrm{~d}$ was more significant than that from $7 \mathrm{~d}$ to $14 \mathrm{~d}$. Taking the $0.5 \%$ fiber content as an example, the unconfined compressive strength of $50 \%$ fly ash cement content of the fiber-reinforced fly ash-cemented marine clay at curing time $7 \mathrm{~d}, 14 \mathrm{~d}$ and $28 \mathrm{~d}$ was 2.23 times, 2.47 times and 2.52 times that of $20 \%$ compound cement content respectively. As a comparison, the unconfined compressive strength of $100 \%$ fly ash cement content of the fiber-reinforced fly ash-cemented marine clay at curing time $7 \mathrm{~d}, 14 \mathrm{~d}$ and $28 \mathrm{~d}$ was 4.67 times, 5.13 times and 5.48 times, respectively, that of $20 \%$ compound cement content. It was shown that the fly ash cement content had a significant effect on the unconfined compressive strength of fiber-reinforced composite-cemented marine clay: the unconfined compressive strength increased significantly with the increase of curing time and the polypropylene fiber content. 


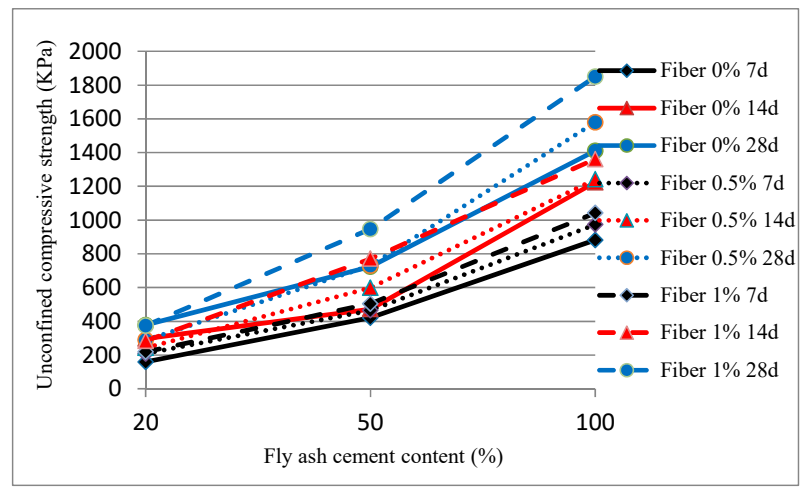

Figure 5. Relationship between unconfined compressive strength and fly ash cement content depending on fiber content and curing time.

\subsection{Effect of Curing Time on Unconfined Compressive Strength}

The relationship between the unconfined compressive strength and the curing time depending on different fiber content and fly ash cement content is shown in Figure 6. The figure indicates that the unconfined compressive strength of polypropylene fiber-reinforced fly ash-cemented marine clay increased with the increase of curing time. Moreover, the growth rate increased more obviously when the curing time increased. Taking the $50 \%$ fly ash cement content and $0.5 \%$ fiber content as an example, the unconfined compressive strength of the fiber-reinforced fly ash-cemented marine clay at curing time $14 \mathrm{~d}$ and $28 \mathrm{~d}$ was 1.29 times and 1.57 times, respectively, than that of $7 \mathrm{~d}$ curing time. The relationship between the unconfined compressive strength and the curing time at $7 \mathrm{~d}, 14 \mathrm{~d}$ and $28 \mathrm{~d}$ can be expressed by Equations (4)-(6), respectively.

$$
\begin{aligned}
& f_{t s}=176.4 \mathrm{e}^{0.16 t} \\
& f_{t s}=373.9 \mathrm{e}^{0.23 t} \\
& f_{t s}=373.9 \mathrm{e}^{0.23 t}
\end{aligned}
$$

where $f_{t s}$ is unconfined compressive strength, $t$ is curing time.

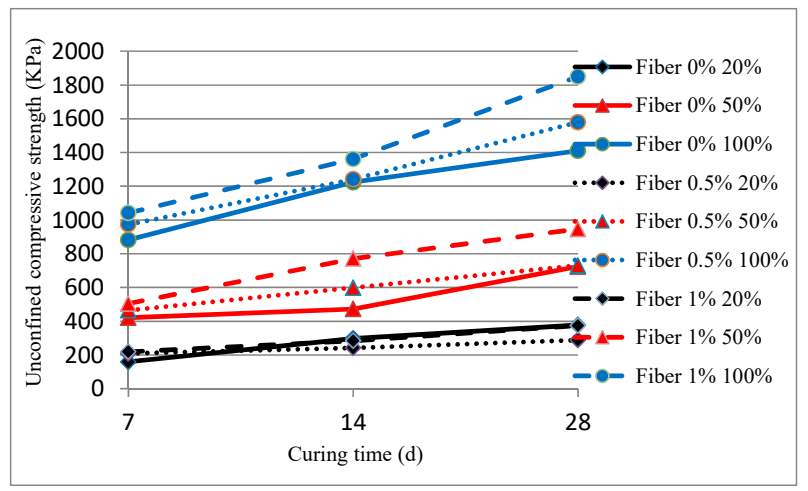

Figure 6. Relationship between unconfined compressive strength and curing time, depending on fiber content and fly ash cement content.

\subsection{Failure Modes}

Taking the $7 \mathrm{~d}$ curing time as an example, the failure photos of fiber-composite cement-reinforced marine clay with $0.5 \%$ polypropylene fiber content are shown in Figure 7. 


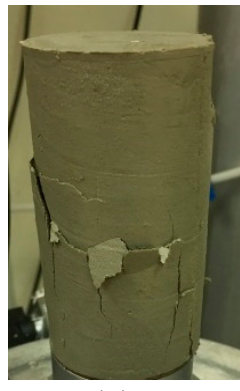

(a)

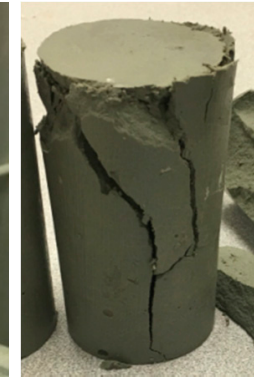

(b)

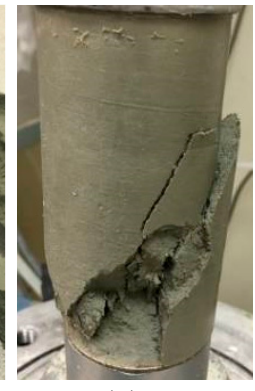

(c)

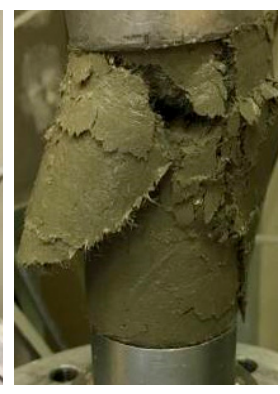

(d)

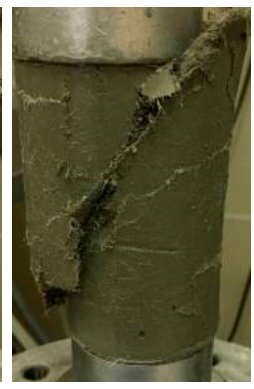

(e)

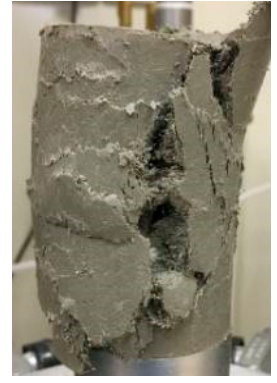

(f)

Figure 7. Failure photos of the specimens with $0.5 \%$ fiber content and $7 \mathrm{~d}$ curing time. (a) $20 \%$ fly ash cement content; (b) 50\% fly ash cement content; (c) 100\% fly ash cement content; (d) 20\% fly ash cement content with fiber; (e) $50 \%$ fly ash cement content with fiber; (f) $100 \%$ fly ash cement content with fiber.

As can be seen from Figure 7, the unconfined compressive strength of the fly ash cement-reinforced marine clay increased with the increase of fly ash cement content; the failure of the specimen gradually showed the characteristics of brittle failure. When $20 \%$ fly ash cement was added, there were no obvious through-cracks in the fly ash cement-reinforced clay. However, samples with $50 \%$ and $100 \%$ fly ash cement content showed obvious through-cracks in a short period of time; specimens with $100 \%$ fly ash cement content showed surface shedding during compression.

Compared with fly ash-cemented marine clay, fiber-reinforced fly ash-cemented marine clay had a longer crack generation time and a slower crack propagation speed under the same conditions. The specimen of fiber-reinforced composite-cemented marine clay showed good plastic deformation after compaction and failure without phenomenon of surface shedding. The tensile stress between the fiber and the fly ash cement-reinforced clay could continue for a long time under the continuous compressive stress though the specimen was already broken. It was affected by the mechanical behavior of the interface between the fiber and the soil particle matrix microscopically. The results were similar to those in reference [16]. The specimen cracked, instead of broke, macroscopically.

\section{Conclusions}

The following conclusions can be drawn according to the tests results:

The peak strength of fiber-reinforced fly ash-cemented marine clay is significantly higher than that without polypropylene fiber except on the condition of $20 \%$ fly ash cement content. The axial strain at the time of failure of fiber-reinforced composite-cemented marine clay is much larger than that without polypropylene fiber under the same conditions, which indicates that the incorporation of polypropylene fiber can effectively improve the peak strength and toughness of the composite cement-reinforced marine clay.

The unconfined compressive strength of fiber-reinforced fly ash-cemented marine clay shows different trends with the increase of fly ash cement content: it increases at first, and then decreases with $20 \%$ fly ash cement content, while it appears an increasing trend with $50 \%$ and $100 \%$ fly ash cement content. The unconfined compressive strength of fiber-reinforced composite-cemented marine clay increases with the increase of fly ash cement content and curing time. The increase trend of the unconfined compressive strength from $14 \mathrm{~d}$ to $28 \mathrm{~d}$ is significantly larger than that from $7 \mathrm{~d}$ to $14 \mathrm{~d}$. The growth rate of the unconfined compressive strength increases with the increase of the curing time and the unconfined compressive strength shows a growth trend of power function.

Composite cemented marine clay forms through-cracks in a short time and shows a brittle failure mode during compression, while fiber-reinforced fly ash-cemented marine clay shows a plastic failure mode which appears that it can continue for a long time after the formation of through cracks. On the microscopic level, it shows continuous tensile stress between polypropylene fiber and composite cement-reinforced marine clay; on the macro level, it became cracked and continuous. 
Author Contributions: Q.C. and J.Z. conceived and designed the study; Q.C. and N.Z. performed the experiments and wrote the paper; Y.G. and S.P. reviewed and edited the manuscript. All authors have read and agreed to the published version of the manuscript.

Funding: This work is funded by the Research Fund of The State Key Laboratory of Coal Resources and Safe Mining, CUMT (SKLCRSM19KF012); Qing Lan Project (2018); Ministry of Housing and Urban-Rural Development Technology Plan (2018-K7-004); Science and Technology Project of Construction System in Jiangsu Province (2018ZD021, 2019ZD083); and the Doctoral Special Fund of Jiangsu Vocational Institute of Architectural Technology (JYBZX18-02).

Acknowledgments: The authors gratefully acknowledge the support provided by National University of Singapore and the Jiangsu Overseas Research \& Training Program for University Prominent Young \& Middle-aged Teacher and Presidents.

Conflicts of Interest: All the authors declare that there are no conflicts of interest regarding the publication of this paper.

\section{References}

1. Liu, Y.; Jiang, Y.; Xiao, H.; Lee, F.H. Determination of representative strength of deep cement-mixed clay from core strength data. Géotechnique 2017, 67, 350-364. [CrossRef]

2. Consoli, N.C.; Da Fonseca, A.V.; Silva, S.; Cruz, R.; Fonini, A. Parameters controlling stiffness and strength of artificially cemented soils. Géotechnique 2012, 62, 177-183. [CrossRef]

3. Kamruzzaman, A.H.; Chew, S.H.; Lee, F.H. Structuration and Destructuration Behavior of Cement-Treated Singapore Marine Clay. J. Geotech. Geoenviron. Eng. 2009, 135, 573-589. [CrossRef]

4. Lee, F.H.; Lee, Y.; Chew, S.-H.; Yong, K.-Y. Strength and Modulus of Marine Clay-Cement Mixes. J. Geotech. Geoenviron. Eng. 2005, 131, 178-186. [CrossRef]

5. Liu, Y.; Chen, E.J.; Quek, S.-T.; Yi, J.-T.; Lee, F.H. Effect of spatial variation of strength and modulus on the lateral compression response of cement-admixed clay slab. Géotechnique 2015, 65, 851-865. [CrossRef]

6. Xiao, H. Evaluating the Stiffness of Chemically Stabilized Marine Clay. Mar. Georesources Geotechnol. 2016, 35, 698-709. [CrossRef]

7. Xiao, H.; Lee, F.H.; Liu, Y. Bounding Surface Cam-Clay Model with Cohesion for Cement-Admixed Clay. Int. J. Géoméch. 2017, 17, 04016026. [CrossRef]

8. Liu, Y.; He, L.Q.; Jiang, Y.J.; Sun, M.M.; Chen, E.J.; Lee, F.-H. Effect of in situ water content variation on the spatial variation of strength of deep cement-mixed clay. Géotechnique 2019, 69, 391-405. [CrossRef]

9. Xiao, H.W.; Wang, W.; Goh, S.H. Effectiveness study for fly ash cement improved marine clay. Constr. Build. Mater. 2017, 157, 1053-1064. [CrossRef]

10. Show, K.-Y.; Tay, J.-H.; Goh, A. Reuse of Incinerator Fly Ash in Soft Soil Stabilization. J. Mater. Civ. Eng. 2003, 15, 335-343. [CrossRef]

11. Zhou, N.; Ouyang, S.; Cheng, Q.; Ju, F. Experimental Study on Mechanical Behavior of a New Backfilling Material: Cement-Treated Marine Clay. Adv. Mater. Sci. Eng. 2019, 2019, 1-8. [CrossRef]

12. Zentar, R.; Wang, D.; Abriak, N.-E.; Benzerzour, M.; Chen, W. Utilization of siliceous-aluminous fly ash and cement for solidification of marine sediments. Constr. Build. Mater. 2012, 35, 856-863. [CrossRef]

13. Xiao, H.; Shen, W.; Lee, F.H. Engineering Properties of Marine Clay Admixed with Portland Cement and Blended Cement with Siliceous Fly Ash. J. Mater. Civ. Eng. 2017, 29, 04017177. [CrossRef]

14. Cheng, Q.; Xiao, H.; Liu, Y.; Wang, W.; Jia, L. Primary yielding locus of cement-stabilized marine clay and its applications. Mar. Georesources Geotechnol. 2018, 37, 488-505. [CrossRef]

15. Anggraini, V.; Huat, B.B.K.; Asadi, A.; Nahazanan, H. Effect of Coir Fibers on the Tensile and Flexural Strength of Soft Marine Clay. J. Nat. Fibers 2014, 12, 185-200. [CrossRef]

16. Tang, C.-S.; Shi, B.; Gao, W.; Chen, F.; Cai, Y. Strength and mechanical behavior of short polypropylene fiber reinforced and cement stabilized clayey soil. Geotext. Geomembr. 2007, 25, 194-202. [CrossRef]

17. Kaniraj, S.R.; Havanagi, V.G. Behavior of Cement-Stabilized Fiber-Reinforced Fly Ash-Soil Mixtures. J. Geotech. Geoenviron. Eng. ASCE. 2001, 127, 574-584. [CrossRef]

18. Correia, A.A.S.; Paulo, J.V.O.; Custódio, D.G. Effect of polypropylene fibers on the compressive and tensile strength of a soft soil, artificially stabilised with binders. Geotext. Geomemb. 2015, 43, 97-106. [CrossRef]

19. Xiao, H.; Liu, Y. A prediction model for the tensile strength of cement-admixed clay with randomly orientated fibers. Eur. J. Environ. Civ. Eng. 2016, 22, 1131-1145. [CrossRef] 
20. Ding, M.; Zhang, F.; Ling, X.; Lin, B. Effects of freeze-thaw cycles on mechanical properties of polypropylene Fiber and cement stabilized clay. Cold Reg. Sci. Technol. 2018, 154, 155-165. [CrossRef]

21. Li, Q.; Chen, J.; Hu, H. The tensile and swelling behavior of cement-stabilized marine clay reinforced with short waste fibers. Mar. Georesources Geotechnol. 2019, 37, 1236-1246. [CrossRef]

22. Chin, K.G.; Lee, F.H.; Dasari, G.R. Effects of curing stress on mechanical properties of cement-treated soft marine clay. In Proceedings of the International Symposium on Engineering Practice and Performance of Soft Deposits, Toyonaka, Japan, 2-4 June 2004; pp. 217-222.

23. Cheng, Q.; Yao, K.; Liu, Y. Stress-Dependent Behavior of Marine Clay Admixed with Fly-Ash-Blended Cement. Int. J. Pavement. Res. Technol. 2018, 11, 611-616. [CrossRef]

24. Geotechnical Investigation and Testing-Laboratory Testing of Soil_ Part 7; ISO/TS 17892; International Organization for Standardization: Geneva, Switzerland, 2004.

(C) 2020 by the authors. Licensee MDPI, Basel, Switzerland. This article is an open access article distributed under the terms and conditions of the Creative Commons Attribution (CC BY) license (http://creativecommons.org/licenses/by/4.0/). 